\section{Effects of In-row Spacing on Eggplant Yield}

\author{
Bielinski M. Santos ${ }^{1,2,3}$
}

AdDitional INDEX wORDs. Solanum melongena, production practices, in-row distance, partial budgets, marginal return rate, economic analysis

SUMMARY. Research was conducted to determine appropriate in-row spacing for eggplant (Solanum melongena) and to determine the best economic returns of this practice. 'Classic' eggplant seedlings were transplanted at in-row distances of 1.0, 1.5, 2.0, 2.5, 3.0, and $3.5 \mathrm{ft}$. Eggplant height decreased linearly as in-row spacing increased. In-row spacing affected total eggplant fruit number, with no fruit number differences among $1.0,1.5,2.0$, and $2.5 \mathrm{ft}$, averaging $\approx 46,800$ fruit/acre. Total fruit weight followed a trend similar to that for total fruit number and there were no differences among 1.0, 1.5, 2.0, and $2.5 \mathrm{ft}$ (ranging between 18.2 and 19.9 tons/acre). From an economical standpoint, the comparison between 2.0 and $2.5 \mathrm{ft}$ resulted in the former spacing having a marginal return rate of $8.03 \%$ in relation to an in-row spacing of $2.5 \mathrm{ft}$, which indicated that growers would earn $\$ 0.08$ extra for each $\$ 1.00$ of net profit by switching from 2.5 to $2.0 \mathrm{ft}$ in-row plant spacing.

$\mathrm{E}$ ggplant is native to India and Pakistan (Rubatzky and Yamaguchi, 1997) and it is a popular vegetable crop among the Hispanic and Asian minorities throughout the United States. Many eggplant types abound, with different shapes, sizes, and colors. However, the preferred types are purple with either round or elongated fruit for consumption by both conventional and ethnic markets. This warm-season solanaceous crop is in the same family as tomato (Lycopersicon esculentum) and peppers (Capsicum annuum).

Worldwide eggplant production has been steadily increasing during the past decade, with major planting areas concentrated in China, India, Egypt, Turkey, and Japan (U.S. Department of Agriculture, 2006). In the United States, there are about 7000 acres in California, Florida, New Jersey, New York, and Georgia (U.S. Department of Agriculture, 2004). Although the exact planted area in Florida is unknown, in 2002 it was $\approx 1200$ acres (U.S. Department of Agriculture, 2006), and it is currently estimated in about 2000 acres in the west central and southern part of the peninsula. In those production areas, eggplant is either transplanted as a stand-alone crop or intercropped with strawberry (Fragaria $\times$ ananassa). When intercropped with strawberry, eggplant transplants at the four-true

${ }^{1}$ Gulf Coast Research and Education Center, IFAS, University of Florida, 14625 County Road 672, Wimauma, FL 33598

${ }^{2}$ Assistant Professor of Horticulture.

${ }^{3}$ Corresponding author. E-mail: bmsantos@ufl.edu. leaf stage are placed in single rows between double rows of strawberry.

Spatial arrangement affects plant biomass allocation and yields. In the United States, research reports dealing with the effect of in-row spacing on eggplant production are rare. Kogbe (1983) found that total fruit yield and number of fruit per plant increased with eggplant spacing, but not average fruit weight. Florida growers use various in-row distances to transplant eggplant, ranging between 12 and 36 inches, whereas the current recommendation is between 18 and 40 inches (Simonne et al., 2006). More research is need to narrow this wide spacing range, which would provide growers with more accurate information for eggplant production and would allow them to use their lands better, especially when increasing urban development in Florida is pressuring agricultural farms to be more efficient. Thus, research was conducted to determine appropriate in-row spacing for eggplant and to determine the best economic returns of this practice.

\section{Materials and methods}

Two field trials were conducted during consecutive seasons in Fall 2005 and Spring 2006 at the Gulf Coast Research and Education Center of the University of Florida in Wimauma, FL. The soil was a sandy, siliceous, hyperthermic Oxyaquic Alorthod with $1.5 \%$ organic matter and a $\mathrm{pH}$ of 7.3. Planting beds were 32 inches wide at the base, 28 inches wide at the top, 8 inches high, and spaced $5 \mathrm{ft}$ apart on centers. Finished beds were fumigated with methyl bromide plus chloropicrin $(67: 33 \mathrm{v} / \mathrm{v})$ at a rate of $175 \mathrm{lb} /$ acre to eliminate soil-borne diseases, nematodes, and weeds in the soil. Simultaneously, each bed was fertilized with $50 \mathrm{lb} /$ acre of a $15 \mathrm{~N}-0 \mathrm{P}-24.9 \mathrm{~K}$ granular formula, and they were covered with 0.6-mil-thick silver on black mulch. Drip irrigation tubing $(0.45 \mathrm{gal} /$ $\mathrm{min} / 100 \mathrm{ft}$ of bed; T-Tape Systems International, San Diego, CA) was buried 1 inch deep down on the bed center. Irrigation was supplied daily both through drip and subsurface irrigation at rates of 5000 and 8000 gal/acre/d respectively. The water table was maintained between 18 and 24 inches deep and was constantly monitored with observations wells located in the fields. Nitrogen and $\mathrm{K}$ were drip injected daily at rates of 1.5 [from transplanting to 2 weeks after transplanting (WAT)], 2.0 (from 3-5 WAT), and 2.5 (from 613 WAT) $\mathrm{lb} / \mathrm{acre} / \mathrm{d}$. For insect and disease management, weekly applications of currently labeled products were performed following current recommendations (Simonne et al., 2006).

'Classic' eggplant seedlings in the four-true leaf stage were manually transplanted 2 weeks after fumigation in single rows on bed tops. In-row distances were 1.0, 1.5, 2.0, 2.5, 3.0, and $3.5 \mathrm{ft}$ in 30 -ft-long plots. These

\begin{tabular}{lllc}
\hline $\begin{array}{l}\text { Units } \\
\text { To convert U.S. to SI, } \\
\text { multiply by }\end{array}$ & U.S. unit & SI unit & $\begin{array}{l}\text { To convert SI to U.S., } \\
\text { multiply by }\end{array}$ \\
\hline 0.4047 & acre $(\mathrm{s})$ & $\mathrm{ha}$ & $2.471 \mathrm{l}$ \\
0.3048 & $\mathrm{ft}$ & $\mathrm{m}$ & 3.2808 \\
3.7854 & gal & $\mathrm{L}$ & 0.2642 \\
2.54 & inch $(\mathrm{es})$ & $\mathrm{cm}$ & 0.3937 \\
0.4536 & $\mathrm{lb}$ & $\mathrm{kg}$ & 2.2046 \\
1.1209 & $\mathrm{lb} / \mathrm{acre}$ & $\mathrm{kg} \cdot \mathrm{ha}^{-1}$ & 0.8922 \\
0.0254 & mil & $\mathrm{mm}$ & 39.3701 \\
2.2417 & ton/acre & $\mathrm{Mg} \cdot \mathrm{ha}^{-1}$ & 0.4461
\end{tabular}


treatments were distributed in a randomized complete block design with five replications, and plots were 40 -ft long and the central 10 plants were used for data collection. Plant height was determined at 6 WAT by measuring the distance between bed tops and the newest open leaf of five plants per plot. Eggplant marketable fruit number and weight per acre were determined over five weekly harvests beginning at 8 WAT. A marketable fruit was defined as without visible injury or deformation and at least 2.5 inches wide and 8 inches long. Fruit weight per plant was calculated by dividing total fruit weight and total plant number per acre for each treatment $(8712,5808,4356$, 3485,2904 , and 2489 plants/acre for $1.0,1.5,2.0,2.5,3.0$, and $3.5 \mathrm{ft}$ respectively).

Data were analyzed with the general linear model procedure to determine the significance of the season-by-treatment interaction and the effects of in-row spacing on eggplant height, and total fruit number and weight were examined with regression analysis. Standard errors were used to separate observed treatment means (SAS version 8.1; SAS Institute, Cary, NC). Best-fitting equations were selected based on the highest significant $r^{2}$ values and the simplest regression models. Maximum predicted yield responses were determined by equaling to zero the first derivative of the quadratic regression equations $\left(y^{\prime}=2 a+b\right.$, where $a$ and $b$ are the equation coefficients) and solving for the corresponding in-row spacing.

For the economic analysis, the partial-budget methodology was applied on the two most promising treatments (Perrin et al., 1988). This methodology uses a two-step procedure: 1) dominance analysis and 2) calculation of the marginal return rates (MRRs). The dominance analysis consists of sorting the treatments based on cost and listing them from lowest to highest, together with their respective net benefit. In moving from the lowest to the highest, any technology that costs more than the previous one but yields less net benefits is said to be "dominated" and can be excluded from further analysis (Evans, 2005; Perrin et al., 1988). The MRR indicates the percentage of net revenue gains of switching from one practice to another and it is calculated as follows: $\mathrm{MRR}=[$ (highest net income $\div$ lowest net income $)-1] \times$ 100.

\section{Results and discussion}

Data from two trials were combined for analysis because the treatment-by-season interaction was nonsignificant. Eggplant height decreased linearly as in-row spacing increased (Fig. 1). Based on the predicted values of the plant height equation, plants at $1.0 \mathrm{ft}$ were $19 \%$ taller than those planted at $3.5 \mathrm{ft}$. The increased height when eggplants were closer to each other was likely the result of the etiolating effect of neighboring plants competing for light, which has been examined extensively in the literature for diverse plant species (Ballaré et al., 1992; Maloof et al., 2000).

In-row spacing affected total eggplant fruit number during both seasons. A quadratic equation described the relationship between inrow spacing and total fruit number, with a maximum predicted value occurring at a spacing of $1.68 \mathrm{ft}$ between plants and declining afterward (Fig. 2). Standard errors among observed means indicated that there were no total fruit number differences among 1.0, 1.5, 2.0, and $2.5 \mathrm{ft}$, averaging $\approx 46,800$ fruit/acre, whereas the treatments with plants spaced at either 3.0 or $3.5 \mathrm{ft}$ resulted in an average of 26,000 fruit/acre, which is $\approx 45 \%$ lower than the total fruit number for the first four distances.

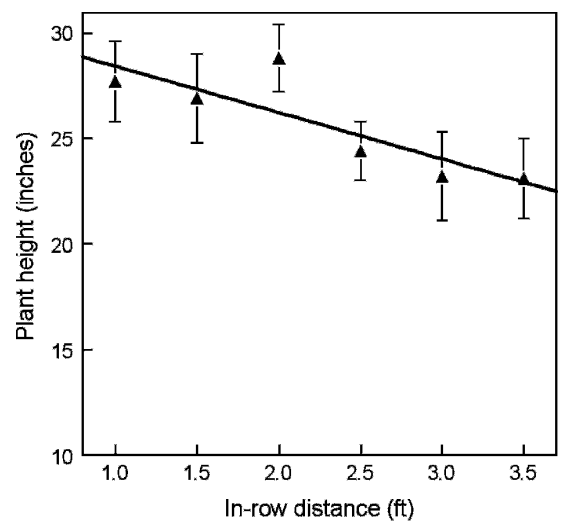

Fig. 1. Effect of in-row spacing on eggplant height at 6 weeks after transplanting. Regression equation is $\mathrm{y}=30.63-2.2 \mathrm{x} ; v^{2}=0.71 .1 \mathrm{ft}=0.3048$ $\mathrm{m}, 1$ inch $=2.54 \mathrm{~cm}$.
Total fruit weight per acre followed a trend similar to that for total fruit number, where the maximum total fruit weight occurred at an inrow spacing of $1.50 \mathrm{ft}$ (Fig. 3). The observed values resulted in no fruit weight differences among $1.0,1.5$, 2.0 , and $2.5 \mathrm{ft}$, ranging between 18.2 and 19.9 tons/acre. In contrast, total fruit weight drastically declined at distances of 3.0 and $3.5 \mathrm{ft}$, producing less than 11 ton/acre. It appears that as in-row spacing increased from 1.0 to $2.5 \mathrm{ft}$ between plants, the intraspecific competition only affected plant height but not total fruit yield.

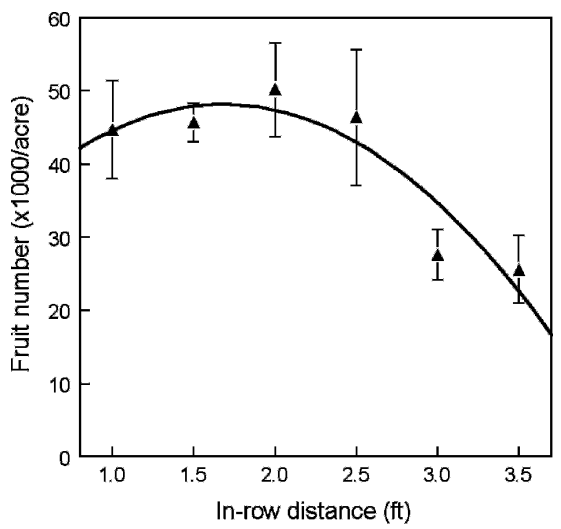

Fig. 2. Effect of in-row spacing on total eggplant fruit number per acre.

Regression equation is $\mathrm{y}=26.29+$ 26.00x $-7.73 \mathrm{x}^{2} ; r^{2}=0.85$. Maximum predicted total fruit number value $(48,153 \mathrm{fruit} / \mathrm{acre})$ occurred at $1.68 \mathrm{ft}$. $1 \mathrm{ft}=0.3048 \mathrm{~m}, 1$ fruit $/$ acre $=2.4711$ fruit/ha.

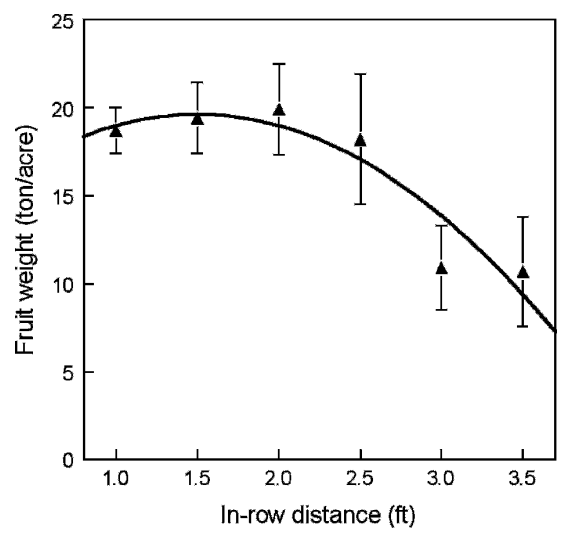

Fig. 3. Effect of in-row spacing on total eggplant fruit weight per acre.

Regression equation is $\mathrm{y}=13.89+$ $7.64 \mathrm{x}-2.55 \mathrm{x}^{2} ; v^{2}=0.86$. Maximum predicted total fruit weight value (19.6 ton/acre) occurred at $1.50 \mathrm{ft} .1 \mathrm{ft}$ $=0.3048 \mathrm{~m} ; 1$ ton $/$ acre $=\mathbf{2} .2417$

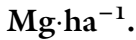


Table 1. Comparison of partial budgets and marginal return rates (MRRs) for eggplant in-row spacing during Fall 2005 and Spring 2006 in Wimauma, FL.

\begin{tabular}{lcc}
\hline & \multicolumn{2}{c}{ In-row spacing $(\mathbf{f t})^{\mathbf{y}}$} \\
\cline { 2 - 3 } Cost components $^{\mathrm{z}}$ & $\mathbf{2 . 0} \mathbf{f t}$ & $\mathbf{2 . 5} \mathbf{f t}$ \\
\hline Marketable yield & 19.9 & 18.5 \\
$\quad$ Fruit wt (ton/acre/season) & 9950.00 & 9100.00 \\
$\quad$ Total gross revenue $(\$ /$ acre $)$ & & \\
Variable costs & 435.60 & 348.50 \\
$\quad$ Transplants $(\$ /$ acre $)$ & 5005.15 & 4577.58 \\
Fruit picking $(\$ /$ acre $)$ & 5440.75 & 4926.08 \\
Total variable costs $(\$ /$ acre $)$ & & 4173.92 \\
Revenues & 4509.25 & \\
Net income $(\$ /$ acre $)$ & 8.03 & \\
MRR $(\%)$ & &
\end{tabular}

${ }^{2}$ Total gross revenue $=$ fruit production $\times$ unit price, net income $=$ total gross revenue - total variable costs, $\mathrm{MRR}=$ $[$ (highest net income $\div$ lowest net income $)-1] \times 100$.

${ }^{y} 1 \mathrm{ft}=0.3048 \mathrm{~m}, \mathrm{l}$ ton $/$ acre $=2.2417 \mathrm{Mg} \cdot \mathrm{ha}^{-1}, \$ 1.00 /$ acre $=\$ 2.471 \mathrm{l} / \mathrm{ha}$

MRR, marginal return rate.

Similar results were reported in cayenne peppers, where wider in-row spacing resulted in shorter plants and less fruit per area than narrower distances (Decoteau and Hatt Graham, 1994).

Predicted values for fruit weight per plant were $4.4,6.8,8.7,9.8,9.5$, and $7.5 \mathrm{lb} /$ plant at distances of 1.0 , $1.5,2.0,2.5,3.0$, and $3.5 \mathrm{ft}$ respectively, with no differences among 2.0 , 2.5 , and $3.0 \mathrm{ft}$ between plants. It appears that the widest eggplant spacing shifted the dry matter partitioning to reproductive structures, likely favoring leaf and stem production. This finding agrees with research reports on the differential effects of spatial arrangements on biomass allocation and plant architecture of strawberry, where excessively wider spaces resulted in lower fruit number per plant than in narrower distances (Hancock et al., 1984). However, they somewhat diverge with those from Kogbe (1983) and Hanna et al. (1987), who found that the number of fruit per plant increased with spacing in eggplant and cucumber (Cucumis sativus) respectively.
From an economical standpoint, the dominance analysis indicated that the two most promising alternatives were 2.0 and $2.5 \mathrm{ft}$ (Table 1). The MRR for $2.0 \mathrm{ft}$ between plants was 8.03\% higher that the MRR for a spacing of $2.5 \mathrm{ft}$, which indicated that growers would earn $\$ 0.08$ extra for each $\$ 1.00$ of net profit by switching from 2.5 to $2.0 \mathrm{ft}$ in-row plant spacing. These results showed that although the same yields are obtained with distances between 1.0 and $2.5 \mathrm{ft}$ between plants, transplanting at an in-row spacing of $2.0 \mathrm{ft}$ provides the highest economic returns.

\section{Literature cited}

Ballaré, C.L., A.L. Scopel, S.R. Radosevich, and R.E. Kendrick. 1992. Phytochrome-mediated phototropism in de-etiolated seedlings. Plant Physiol. 100:170-177.

Decoteau, D.R. and H.A. Hatt Graham. 1994. Plant spatial arrangement affects growth, yield, and pod distribution of cayenne peppers. HortScience 29:149151.
Evans, E.A. 2005. Marginal analysis: An economic procedure for selecting alternative technologies/practices. Inst. Food Agr. Sci. Publ., Univ. of Florida, Gainesville, FL.

Kogbe, J.O.S. 1983. Effects of spacing on the yield of local and exotic species of eggplant. Acta Hort. 123:291-297.

Hancock, J.F., J.W. Moon, and J.A. Flore. 1984. Within-row spacing and dry weight distribution in two strawberry cultivars. HortScience 19:412-413.

Hanna, H.Y., A.J. Adams, and R.N. Story. 1987. Increased yield in slicing cucumber with vertical training of plants and reduced plant spacing. HortScience 22:32-34.

Maloof, J.N., J.O. Borevitz, D. Weigel, and J. Chory. 2000. Natural variation in phytochrome signaling. Cell Developmental Biol. 11:523-530.

Perrin, R., J. Anderson, D. Winkelmann, and E. Moscardi. 1988. From agronomic data to farmer recommendations: An economics training manual. CIMMYT, Mexico City.

Rubatzky, V.E. and M. Yamaguchi. 1997. World vegetables. 2nd ed. Chapman and Hall, New York.

Simonne, E.H., W.M. Stall, K.L. Pernezny, S.E. Webb, T.G. Taylor, and S.A. Smith. 2006. Eggplant production in Florida, p. 239-251. In: S.O. Olson and E.H. Simonne (eds.). Vegetable production handbook for Florida, 2006-2007. Inst. Food Agr. Sci. Publ., Univ. of Florida, Gainesville, FL.

U.S. Department of Agriculture. 2004. Statistics of vegetables and melons, 2004. 12 May 2007. <http://www.usda.gov/ nass/pubs/agr04/04_ch4.pdf>.

U.S. Department of Agriculture. 2006. Vegetables and melons outlook, Dec. 2006. 12 May 2007. <http://www.ers. usda.gov/publications/vgs/2006/ $12 \mathrm{dec} / \mathrm{vgs} 318$.pdf $>$. 